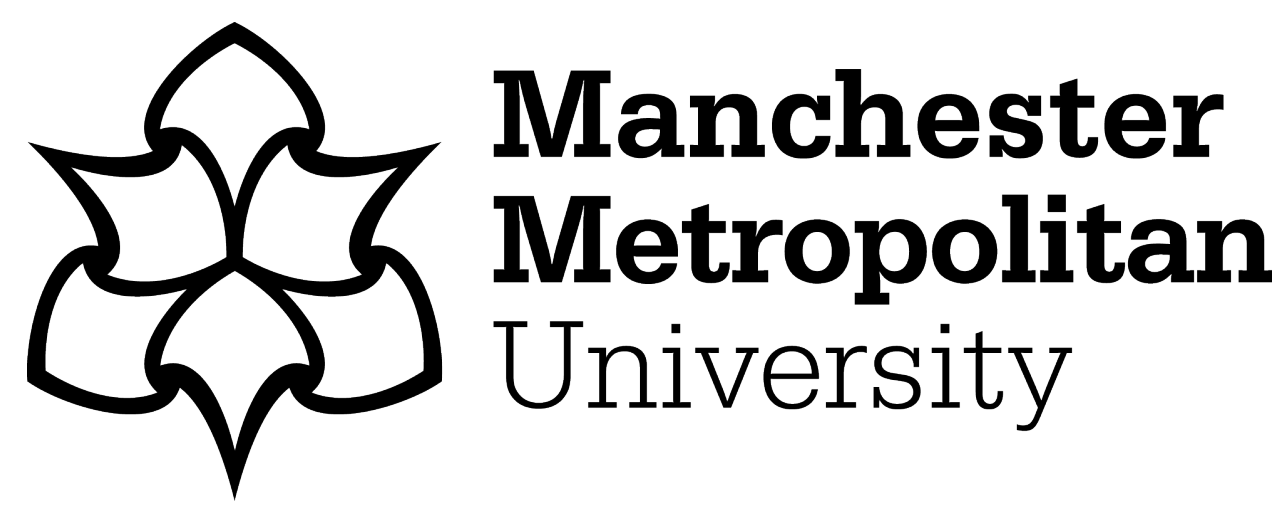

Cao, Q, Criscuolo, Paola and Autio, Erkko (2016) SME internationalisation and Its impact on firm performance. In: Impact of International Business Challenges and Solutions for Policy and Practice. The Academy of International Business . Palgrave Macmillan, pp. 220-240. ISBN 1137569468

Downloaded from: https://e-space.mmu.ac.uk/621213/

Version: Accepted Version

Publisher: Palgrave Macmillan

Please cite the published version 


\title{
12
}

\section{SME Internationalisation and Its Impact on Firm Performance}

\author{
Qi Cao, Paola Criscuolo and Erkko Autio
}

\section{Introduction}

The past decade has witnessed a growing interest in research on the internationalisation of small and medium-sized enterprises (SMEs). After two decades of development in international SME literature, both business practitioners and researchers in the field of international business and entrepreneurship are starting to consider whether and how multinationalisation impacts the performance of small and medium-sized firms. Lu and Beamish (2001) state that research in this field should 'examine the effects of an international aspect of an entrepreneurial strategy'. In this context, internationalisation is a strategic choice and the focus will be on the consequences of such entrepreneurial activity. McDougall and Oviatt (1996) point out that the impact of multinationalisation on firm performance is one of the most significant concerns in the field. This topic is critical for both business managers who need to take strategic decisions as to whether or not to go global, and for researchers who are trying to unveil the real effects of internationalisation on firm survival and growth.

The majority of the existing literature on SME internationalisation focuses on what sort of firms become international. Few studies examine the consequences of the market entry strategy. The lack of empirical evidence is overshadowed by the incoherent theoretical lenses employed to explain SME internationalisation process. Although a number of studies have tested the relationship between SME internationalisation and firm performance, both empirically and theoretically, research has so far proved inconclusive (Westhead et al., 2004). A 'positive', 'negative' or non-linear relationship does not mean necessarily that individual firms will follow 'positive', 'negative' or non-linear performance trajectories. Within the scope of international business literatures, studies on MNEs' degree of internationalisation (DOI) performance gave a loose conclusion that internationalisation has a positive effect on firm performance (Pangarkar, 2008). 
However, SMEs may experience a more complicated situation while going global. A typical anticipation of the relationship between SME multinationalisation and firm performance is a 'U-curve' which indicates a deteriorate performance at the beginning of internationalisation due to the shock of foreignness and resource constraint. In the long term, however, a pickup could happen when the benefit of new opportunity overcomes the negative impact (Orser et al., 2000; Shrader et al., 2000). However, as the authors point out, for SMEs, empirical studies have provided contradictory results as to whether there is a positive or negative relationship between multinationalisation and performance.

Building on the review of relevant literatures, this chapter aims to define the frontier of current research by identifying and grouping the most prevalent mechanisms and factors influencing SME performance outcome during the process of internationalisation. The main research focuses are whether and how different mechanisms transfer the changes of internationalisation to firm performance. Instead of distinguishing different types of SMEs, we rely on firm-level theoretical frameworks that have been employed previously in SME internationalisation studies. Indeed, there are differences in internationalisation of international new ventures (INVs), born-globals and well established international SMEs. As Autio et al. (2000) point out, the age of initial internationalisation could shift the growth strategy, international identity, learning process and many aspects of the firms. That aside, start-ups and INVs are all SMEs in an early stage of establishment.

Among a few significant areas of study, we argue that the following three aspects of SME internationalisation and performance study make research in this area critical. First, abundant literature has focused on the relationship between the degree of international and financial performance of MNEs (Sullivan, 1994), but much less has explored the relationship between the internationalisation and firm performance of SMEs. Second, existing literature on the performance and internationalisation of SMEs (Autio et al., 2000; Zahra et al., 2000; Lu and Beamish, 2001; Qian, 2002; Westhead et al., 2004; Pangarkar, 2008) tries to find empirical evidence for a positive relationship between SME multinationalisation and financial performance. However, the mechanism of whether and how internationalisation impacts firm performance is still unclear ( $\mathrm{Lu}$ and Beamish, 2001). Last but not least, the literature on entrepreneurship has focused on explaining and legitimating international new venture (INV) multinationalisation. The theoretical methods, however, are derived from international business literature and strategic management theories. Resource-based theory (RBV) (Barney, 1991) and knowledge-based analysis (KBV) (Gilbert et al., 2008) are the most commonly employed methods. RBV and KBV, however, are based on research on large companies. As SMEs are not 'smaller versions of MNEs' (Shuman and Seeger, 1986), a theoretical 
framework has not been established for the impact of multinationalisation on the performance of resource-constrained, routine absent small and mediumsized businesses.

\section{Theoretical background}

In traditional international business (IB) literature, SMEs are not the main object of study. Sullivan (1994) reviewed the literature on DOI performance research from 1970 to 1990. No empirical study employs SMEs as a research sample. On the contrary, companies described as 'the largest U.S. MNCs' (Geringer et al., 1989) and 'Fortune 500' (Vernon, 1971) constitute the whole empirical sample in studies of firm internationalisation. The observation of large companies' trajectories of foreign market entry revealed that mature companies take a few steps to realise the great potential of both downstream market places and upstream resources from foreign countries. This was concluded as process international theory (PIT), which is based on the assumption that incremental changes are made through a path-dependent progress of business patterns (Johanson and Vahlne, 1977; Welch and Luostarinen, 1988). According to PIT, only at certain development levels do companies start to go to the global stage (Johanson and Vahlne, 1990; Autio, 2005). PIT legitimated the internationalisation process of large companies by assuming that companies pursue longterm profitability and keep away from business activities with high uncertainty (Johanson and Vahlne, 1977). Considering SMEs that face resource constraints, uncertain market environments and limited business routines, internationalisation should be avoided. This diverges widely from the reality of SME multinationalisation, therefore a new focus was established by the last decade of the 20th century which began with the observation of the international activities of SMEs and new ventures (Oviatt and McDougall, 2005).

Oviatt and McDougall's 1994 paper is considered the inception of the study of new venture internationalisation (Autio, 2005). The authors argue that the developments in the international business environment since the late 1980s have increased the exposure of SMEs to international activities. The improvements include easier cross-national communication and transportation technology, increased homogeneity of market characters in different countries, more entrepreneurs with multinational operating experience, and flourishing cross-border financial resources (Oviatt and McDougall, 1994). PIT cannot explain the emerging phenomenon of SMEs going global. The exiguous resource availability of SMEs also challenged the traditional RBV theory of resource possession and allocation (Barney, 1991). If an established company's internationalisation is a strategic have-to (considering both resources and market position), the multinationalisation of SMEs is more like a strategic option, or is more in the nature of an opportunistic incentive. 
The consequence of research on international SMEs is significant; a new research field, international entrepreneuiship (IE), has been established and is considered a critically distinguished field of international business study (Autio, 2005). The definition of IE has been continuously evolving through the past two decades, from the early focus on the international activities of new ventures (McDougall et al., 1994) to the recent research on entrepreneurial internationalisation (Autio et al., 2010; Keupp and Gassmann, 2009). The trend reflects the shift in research focus from company size and age to an emphasis on entrepreneurial activities. The relationship between IE study and international business literature has been discussed intensively (Oviatt and McDougall, 1994, 2005). Lu and Beamish (2001) argue that IE study is bonded with SME internationalisation literature in that the 'internationalisation of an established yet small firm' is an emerging significant stream of IE research beside the original focus on start-ups and INVs. Indeed, start-ups and INVs are also SMEs in an early stage of establishment. For example, as discussed above, the incentive of a new venture's internationalisation has been explored from demographical, resource-based and strategic aspects. Gilbert et al. (2008) summarise that entrepreneur characteristics, resources, geographic location, strategy, industry context, as well as organisational structure and systems, are critical factors that shape the success or failure of SME internationalisation.

A large percentage of the literature of SME internationalisation and performance focuses on the moderating effects of a single variable, for example organisational learning, or of a couple of correlated variables, such as organisational learning, prior knowledge stock and company absorptive capacity (McDougall and Oviatt, 2000; Teece et al., 1997; Autio et al., 2000; Zahra et al., 2000; Sapienza et al., 2006; Jantunen et al., 2005; Rasheed, 2005; Gray, 2006; Avlonities and Salavou, 2007; Frishammar and Andersson, 2009). These studies have a few inherent disadvantages: the causal links between dependent and independent variables are controversial; correlation between variables can lead to biased empirical results; and the boundary of the control group is unclear. The correlation of a large number of factors leads to empirical results that are too narrowly focused and do not hold when different data are employed. Since there is no conclusion from past literatures as to which factors significantly influence SME internationalisation and performance process, it is necessary to explore all the factors which appear in the literature. Dozens of factors that influence SME performance and the multinationalisation process have been employed in theoretical and empirical studies. Some proxies of these mechanisms have been proposed in the literature. Examples include R\&D intensity (Teece et al., 1997; Autio et al., 2000; Bausch and Krist, 2007; Muscio, 2007; Teece, 2007; Hsu and Pereira, 2008; Shimizutani and Todo, 2008; Frenz and Gillies, 2009), prior knowledge stock (Zahra et al., 2000; Gray, 2006; Muscio, 2007, Teece, 2007; Hsu and Pereira, 2008; Bingham, 2009) and product 
diversification (Geringer et al., 1989; Teece et al., 1997; Zahra et al., 2000; Bausch and Krist, 2007; Gaur and Kumar, 2009). The theoretical gap lies in the fact that the effects of the firm's resource base, growth strategy and strategic position on SME internationalisation and consequent firm performance have not been sufficiently explored.

In general there are three major types of mechanism, namely organisational capabilities, resource endowments and strategic orientations. Regarding organisational capabilities, following the organisational capability approach of Autio et al. (2010), Zahra et al. (2000) and Zahra and George (2002), a company's ability to achieve growth and better performance depends on its substantive capabilities and change capabilities. In a nutshell, change capabilities include factors that improve a company's ability to achieve success when change happens, while substantive capabilities help a company improve the capability of its routines and daily production. The second major category is resource endowments, which includes organisational endowment, environmental endowment and resource optimisation. This approach focuses on a firm's inherent properties and resource-based advantages (Penrose, 1959; Rumelt, 1984; Barney, 1991). MNE internationalisation studies based on international business literature largely rely on resource endowment analysis (Dunning, 1988; Sullivan, 1994; Contractor, 2007; Li, 2007). The third major category is strategic legitimacy. SME internationalisation studies based on strategic management and international entrepreneurship research pay more attention to individual and organisational strategic orientations and their impact on firm performance (Dimitratos et al., 2004; Firshammar and Andersson, 2009). On an individual level, demographic characteristics of the management team focuses on a manager's personal experience in multinationalisation and the managerial team's diversity of knowledge. Many studies have proved that an entrepreneurial team's experience and knowledge stock have significant impact on internationalisation implications (Jantunen et al., 2005; Avlonities and Salavou, 2007). On an organisational level, company strategic orientation includes a firm's strategy preference towards multinationalisation, company risk tolerance level, market entry model and willingness to bring change to the business. Strategic legitimacy also concerns the credibility change after multinationalisation activities. These factors are traditionally highlighted in the internationalisation and performance study of MNEs, and are worth digging into in the study of SMEs as well.

Based on the above review, we propose a research model for the performance consequences of SME internationalisation which uses a series of mechanisms to deliver the changes brought by multinationalisation to performance. These mechanisms include change capabilities, substantive capabilities, organisational endowment, environmental endowment, resource optimisation, demographic characteristics of the management team and strategic legitimacy (Table 12.1). 
Table 12.1 Mechanisms and factors employed in SME internationalisation impact studies

\begin{tabular}{|c|c|}
\hline Mechanisms & Factors \\
\hline \multicolumn{2}{|l|}{ Organisational capabilities } \\
\hline \multirow[t]{3}{*}{ Change capabilities } & Dynamic capability \\
\hline & Organisational learning \\
\hline & Absorptive capacity \\
\hline \multirow[t]{3}{*}{ Substantive capabilities } & $\mathrm{R} \& \mathrm{D}$ intensity \\
\hline & Prior knowledge stock \\
\hline & Product/Market diversity \\
\hline \multicolumn{2}{|l|}{ Resource endowments } \\
\hline \multirow[t]{2}{*}{ Organisational endowment } & Firm age \\
\hline & Firm size \\
\hline \multirow[t]{2}{*}{ Environmental endowment } & Location, network and cultural distance \\
\hline & Industry dynamics \\
\hline \multirow[t]{2}{*}{ Resource access and optimisation } & Resource position \\
\hline & Resource fungibility \\
\hline \multicolumn{2}{|l|}{ Strategic orientations } \\
\hline \multirow[t]{2}{*}{ Demographic characteristics } & Manager's business/ intl. experience \\
\hline & Managerial team diversity \\
\hline \multirow[t]{4}{*}{ Strategic legitimacy } & Firm strategy \\
\hline & Risk tolerance \\
\hline & Market entry model \\
\hline & Strategic change \\
\hline
\end{tabular}

Change capabilities cover a few factors which help businesses improve performance in the dynamic process of change. Dynamic capability, organisational learning and absorptive capacity are the three most prevalent factors in this domain. Substantive capabilities include R\&D intensity, prior knowledge stock, product diversity and the routines and patterns of a firm. These factors facilitate daily operations and performance of the business. Organisational endowment mainly focuses on firm properties like firm age, firm size and so on. Environmental endowment includes external factors like economy of scale, cultural distance, social network and industry dynamics. Resource access and optimisation focuses on factors related to resource-based perspective, including resource position and resource fungibility. The eight factors in the category of resource endowment could be seen as properties of a firm which describe the firm's development stage and define its resource position in the marketplace. Demographic characteristics of the management team focuses on the individual-level capability of the management group which includes the manager's business experience and managerial team diversity. Strategic legitimacy offers a credibility perspective on the firm's ability to deal with changes. The firm's strategy making, risk tolerance level, market entry model and willingness to bring change to the organisation are all factors which measure credibility. 


\section{Conceptual framework and proposition-developing}

\section{Change capabilities}

As argued earlier, internationalisation is a process of bringing change to a company. How well SMEs adapt to the changing internal structure and external environment during the internationalisation process could determine whether or not the companies survive the initial impact of foreignness. Teece et al. (1997) propose that a company's ability to employ both internal and external resources to adapt to a rapidly changing environment may be considered its dynamic capability. The internationalisation of SMEs impacts firm performance by introducing changes and new opportunities. As discussed above, these changes influence both the internal and external structure of the firm. Compared with established multinational companies, SMEs face severe resource and knowledge-stock constraints. However, this does not mean SMEs are in an inferior position in the internationalisation process compared to MNEs. From the dynamic capability perspective, abundant knowledge or technology stock and access to scarce resources are not essential to secure a competitive advantage. It is the ability to respond swiftly to market and technology changes that enables a firm to achieve success.

In the internationalisation context, market change is largely due to entry to new markets when SMEs go global. Past literature on learning capability and knowledge transfer has pointed out the inertness of replicating the successful practice of doing business from the home market to the host country (Kogut and Zander, 1992; Teece, 1986; Cohen and Levinthal, 1990). Before replicating the original practice to a new market, a firm needs to understand its patterns of doing business. Routines and patterns developed by the company are highly path-dependent and not easy to codify and replicate (Kogut and Zander, 1992). Since successful practice and tacit knowledge are the results of learning-bydoing (Malerba and Orsenigo, 1993), the transfer of knowledge and practice from domestic market to foreign market could be improved by prior experience of market expansion. SMEs learn from their experience and accumulate the routines and patterns of replicating and transferring business practice and knowledge.

Proposition 1(a) SMEs with previous experience of entering new markets have obtained relevant capability for geographic expansion, which facilitates performance in the host market.

Coff (1999) argues that a firm is not a unitary role but is constituted by many stakeholders with different interests; therefore, a firm can be seen as a nexus of contracts. Since a firm consists of individuals, small working groups, teams and departments which all have different interests, focuses and knowledge 
stocks, the exploitation of knowledge stock within the firm is difficult. Similarly, the transfer of technology within the firm also faces obstacles (Teece, 1986). Szulanski (1996) describes these impediments within a firm as 'internal stickiness' which originates from the causal ambiguity of knowledge itself, lack of perceived reliability of sources, lack of absorptive capacity of the recipient and the arduous relationship within the organisational context. In the multinationalisation context, in most cases SMEs expand their operating branches as well as employee numbers when entering a new market. The expansion leads to a more complicated organisational structure and greater distances between individuals and working units. We argue that it is difficult for SMEs to exploit existing knowledge stock when an organisation expands over national borders (Contractor, 2007). This leads to the following proposition:

Proposition 1(b) Internationalisation of SMEs increases the complexity of the organisational structure which hinders the exploitation of knowledge within the firm and eventually offsets the benefits of cross-border market expansion.

\section{Absorptive capacity and learning effects in SMEs}

Absorptive capacity has been widely accepted as a theoretical framework that offers a distinctive perspective alongside the resource-based view (RBV) (Barney, 1991), knowledge-based analysis (KBV) (Kogut and Zander, 1992), technology and industry change (Dosi, 1982; Malerba and Orsenigo, 1993; Audretsch, 1997) and the dynamic capability perspective (Teece, 2007; Cohen and Levinthal, 1990) on firm internationalisation and performance studies. Cohen and Levinthal (1990, p. 447) define absorptive capability (AC) as a firm's ability to 'recognize and assimilate external information and apply it to commercial ends'. There are three fundamental aspects to this approach: (1) identify the new external knowledge; (2) assimilate the information and knowledge from the new environment; and (3) apply the external knowledge to enhance the firm's own competitiveness. These three aspects are progressively related to one another (Figure 12.1). The first step concerns identifying new technology and recognising opportunities, which is a fundamental requirement for companies exploring new technological opportunities. The second step of assimilating external knowledge focuses on the learning process whereby a firm recodes new knowledge into a common language which can be understood, communicated and replicated within the boundary of the organisation. In the third step the knowledge is applied to firm practice, which emphasises the organisational ability to exploit inner knowledge stock and apply ideas to production. Cohen and Levinthal (1990) proposed that organisational absorptive capacity is a function of prior knowledge stock. Similarly, Kogut and Zander (1992) argue that organisational learning capability cannot 
be separated from what the firm already knows, that is, the knowledge stock of the company. Their rationale lies in the view that what the company did in the past shapes what they can do in the future. Although in many cases the knowledge stock may not be particularly useful for future development, a rich knowledge stock and operational experience are considered solid ground for better organisational learning capability in the future. Therefore, SMEs with better prior knowledge stock and experience of pattern and routines will have more chance to improve performance.

Proposition 1(c) SMEs with abundant prior knowledge stock explore host market knowledge and information more efficiently, which leads to superior performance.

Oviatt and McDougall (1994) argue that to achieve sustainable growth SMEs have to rely on local (host country) knowledge assimilation and capability development. Exploration of local knowledge and acquisition of host country R\&D capabilities therefore is vital to (1) survive in foreign market and (2) achieve profitability in the long term. The adoption of local intangible resources and knowledge-based capacity could improve overall firm performance. Smaller firms have small organisation, fewer power levels and are more homogenous in many aspects in the internationalisation process. MNEs, however, have different departments, lots of subsidiaries and complicated power structure. As a single small company, learning effects, knowledge assimilation and international experience provide more visible impacts compared with MNEs. Although learning effects happen in both SMEs and MNEs, we argue it is more

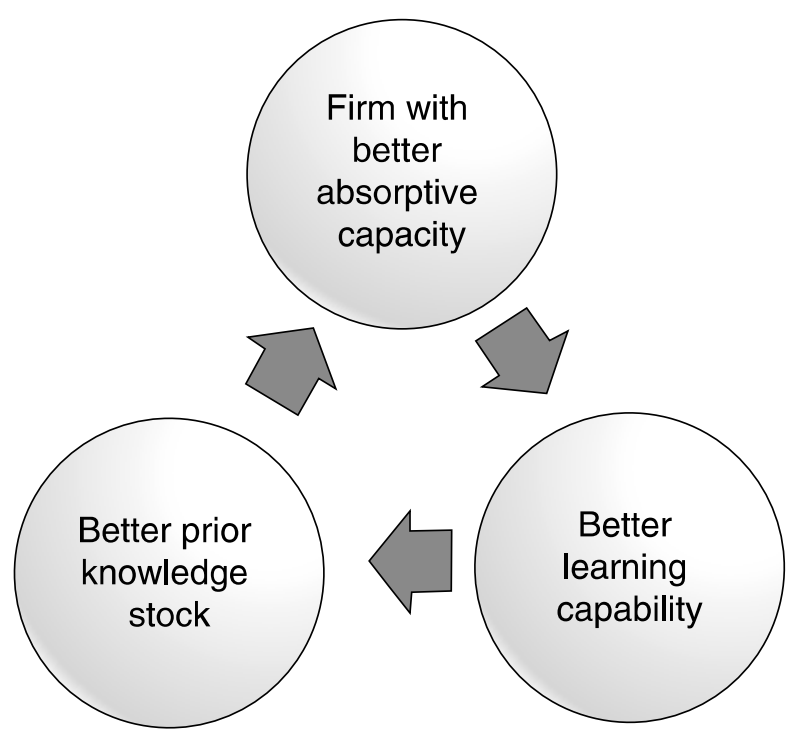

Figure 12.1 Self-enhancing relationship between absorptive capacity, learning capability and knowledge stock 
visible in SMEs. Also, SMEs rely more on host country resources and knowledge to achieve success.

Proposition 1 (d) SMEs rely on host market knowledge exploration to achieve sustainable growth.

\section{Substantive capabilities}

Substantive capabilities enable firms' daily business operation to run smoothly and efficiently (Autio et al., 2010; Zahra et al., 2000). Autio et al. (2010) argues that substantive capabilities improve routine business practice by 'minimiz[ing] variance and maximize operational efficiency'. Firms' substantive capabilities are widely discussed and considered vital factors in MNE internationalisation studies. A specific focus is on firms' incremental innovation capabilities. R\&D intensity, firm prior knowledge stock and product/market diversity are the most significant components in substantive capabilities catalogue.

Firm R\&D intensity has been considered a critical indicator of firm innovative capability and major measurement of firm's intangible knowledge level (Frenz and Gillies, 2009). Teece et al. (1997) state that R\&D intensity has been employed in resource-based analysis as a threshold preventing outsiders entering the market. $R \& D$ activities at the same time are considered the major resource of incremental and radical technology improvements from a product life-cycle perspective. $R \& D$ intensity is firmly connected with company prior knowledge stock. Higher R\&D intensity builds up in-house technology stock and enables a company to identify and assimilate external knowledge. Abundant firm knowledge stock at the same time could provide solid ground for in-house $R \& D$ activities. A positive mutual relationship between R\&D intensity and prior knowledge stock has been widely accepted (Muscio, 2007; Hsu and Pereira, 2008).

Proposition 2 (a) R\&D intensity, indicating firm technological capabilities and intangible knowledge level, is positively related to SME performance in domestic environment.

Early 'degree of internationalisation' literatures employ foreign sales to total sales ratio (FSTS) or foreign assets to total assets ratio (FATA) as common measurements of firm multinationalisation level; the international diversification performance (IDP) literature however argues that DOI is not sufficient. The major argument is that firms operating in a few foreign markets with diverse culture and market environment could gain more business opportunities compared with firms operating in specific foreign markets (Hsu and Pereira, 2008). The empirical result, similar to performance implication research, is inconclusive. From a dynamic capability perspective, we believe that learning 
and assimilating of new market knowledge leads to complicated organisational structure and higher managerial costs. Entering a new business environment is always risky for SMEs; at least in the short term new market entry will negatively influence firm performance. Host markets with diverse cultural, political and market backgrounds are a challenging environment for SMEs. It is advisable then to enter market clusters with similarity and geographical proximity.

Proposition 2 (b) Market diversification requires sufficient time for SME adapt to new environment; a negative impact will be induced by market diversification on firm performance in the short term.

\section{Organisational Endowment}

Organisational endowment is simply composed of two company properties, firm age and size. Although it is explicitly defined, these two factors have been widely addressed in firm internationalisation studies. The first element, firm age, is an important indicator of a company's business experience and existing knowledge stock. At the same time, business experience and knowledge stock are is the essential part for business routines' and patterns' development (Orser et al., 2000; Sapienza et al., 2006). According to process internationalisation theory, these patterns and routines are critical during the process of multinationalisation (Johanson and Vahlne, 1977, 1990; Welch and Luostarinen, 1988).

Following Oviatt and McDougall's (1994) argument, Sapienza et al. (2006) state that earlier internationalisation is not only possible but also provides significant advantage for companies in that the 'imprint effect' of dynamic capabilities will be more efficient as a firm multinationalises at an earlier stage of its development. Autio et al. (2010) state that well-established companies accumulate abundant substantive capabilities through years of operation. We propose that firm age facilitates company daily operations, which as Sapienza et al. (2006) point out may hinder future international profitability. We therefore propose that firm age has a positive relationship with company substantive capabilities. Change capabilities at the same time are not dependent on firm age or firm size but organisational experience of change.

Proposition 3 SMEs gain substantive capabilities through daily operation, firm age and size and this therefore has a positive relationship with domestic and substantive knowledge stock.

\section{Network, environment and industry dynamics}

The above organisational endowment mechanism focuses on firms' internal characteristics while environmental endowment focuses on companies' external environment. Apart from location choice and cultural distance which 
have been intensively studied in international business literatures, there are two major factors in this section attracting our attention: network perspectives and industry dynamics.

Dana (2001) points out that SMEs have established networks on all aspects of business activities. On individual level, entrepreneurs and business managers rely on an interpersonal network to exploit business opportunities and information. Ethnic groups, industrial associations and other forms of groups provide business owners a platform to exchange information and knowledge and achieve growth together. On firm level, SMEs not only participate in small business networks but also form alliances with large companies, acting as supplier, outsourcer or buyer. Wright et al. (2007, p. 1021) conclude that from a resource-based perspective, networking provides SMEs the opportunity of utilising 'external tangible and intangible assets' that complement limited internal fungible resources. This is critical for SMEs in the process of market entry. Dimitratos et al. (2012, p. 711) state that network perspective in internationalisation context focuses on the extent to which the firm obtains resources from the external environment though alliance creation and social embeddedness in order to use in its activities in markets abroad'. Social networking therefore is an approach of knowledge and opportunity exploration in the foreign market place. Since international SMEs rely on host country knowledge and opportunities to overcome the effects of foreignness, network plays a critical role that determines the outcome of SME market entry activities.

Proposition 4 (a) Social networking facilitates SME performance in internationalisation process.

On the firm level, networking between organisations enables SMEs to act as part of a symbiotic group of firms, cooperating with one another in the markets (Dana, 2001). Similar to social networks, business networks, e.g. business alliances, local partner companies and joint ventures, provide a platform for SMEs to explore external resources and opportunities. Business alliances not only share resources, but also share the risks and shocks of foreignness in the internationalisation process. SMEs could form different business networks with various kinds of companies. Wright et al. (2007, p. 1022) argue that SMEs could be 'pulled into foreign market by large network partners' and 'borrow size and resources' from the companies. Large firms in a business network could facilitate smaller firms' market entering activities. In the meantime, smaller firms have to synchronise their progress with the large network partner to survive the new environment. Alliances with host country firms could also reduce the risks associated with market entry activities and allocate resources more efficiently between local and market exploring firms (Laufs and Schwens, 2014). 
Although SME internationalisation strategies are diverse, networks facilitate market entry process by providing resources and opportunities.

Proposition 4 (b) Business alliances facilitate SME performance in internationalisation process.

Environmental factors like company industrial position's impact on SME internationalisation process has been mentioned in many literatures. Zahra and George (2002), for example, argue that environmental elements, that is, industries firms engaged in, could have great impact on firm internationalisation. Similarly, Fernhaber et al. (2007) propose that firms engaged in fast-growing industry, knowledge-intensive industry, highly integrated industry and highly venture capital reliance industry have more likelihood of going global. They point out the linkage between industry endowment of firms and internationalisation, as well as the performance after going global is yet to be explored. Firms engaged in different industrial environments may have great divergence in prior development route before going global. High-tech new ventures, for example, may have a high expectation of globalisation at early stage of establishment and enhance their change capabilities deliberately.

Proposition 4 (c) SMEs engaged in fast-growing, knowledge-intensive, highly integrated, and/or highly venture capital reliance industry have high expectation of globalisation which enables these companies to achieve better performance compared with other companies in different industry.

\section{Resource access and optimisation}

Resource position perspective derives from the resource-based theory of firm competitive advantage (Barney, 1991). It has been long established and well developed in international business literatures. The basic assumption is that access to specific non-imitable resources enables firms to outperform competitors (Barney, 1991). Hsu and Pereira (2008) propose a positively related model between company resource position and firm performance after market entry by dividing the process into two stages. First, according to resource-based view, abundant resource offers product advantage (tangible resource) and knowledge enables firms to expand over country borders (intangible resource). Second, three aspects of organisational learning were introduced: social learning, technological learning and market learning which are positively related to firm performance in host markets. A basic assumption is that resource possession has a positive relation with firm performance. Sapienza et al. (2006) define resource fungibility as resource's attribute of whether it could be used in wide range of business functions or focused on certain business operations. Sapienza et al. propose that higher resource fungibility level could reduce the cost of utilising resources which in turn reduces the risks of failure during SMEs' 
multinationalisation process. Following Penrose's (1959) resource dependence theory, George (2005) argues that it is fungible resources, instead of resource stock as past RBV literature suggests, that facilitate company strategic activities. We therefore propose:

Proposition 5 Deploying fungible resources efficiently and effectively could positively influence the outcome of SME market entry activities.

\section{Demographic characteristics of the management team}

Management team demographic characteristics, for example manager's demographical background, management team experience, managerial diversity and so on, are important factors influencing SME internationalisation and performance outcomes. Oviatt and McDougall (2005) state that international entrepreneurship (IE) is a behaviour-based that study focuses on proactive actions managers conduct to add new value to company in the context of multinational market entry. The major concern, as Shane and Venkataraman (2000) argue, is on how to find business opportunities and personnel's role in this value-adding adventure. Two factors are critical in this opportunity-identifying process: manager's business experience and managerial team diversity. The first factor, entrepreneur experience, is significant in that entrepreneurs' personal international experience influence the decision-making of time of entry, partnership forming, information collecting, learning capabilities and many other aspects of multinationalisation process (Bingham, 2009; Frishammar and Andersson, 2009). For SMEs, the significance of entrepreneur's role in multinationalisation is more vital compared with established companies. MNEs have a complicated decision-making process which ensures business action follows the right route and looks at the most efficient methods. SMEs often have a less sophisticated management system which means the decision-making relies on individual managers or a few people in the managerial team. The presence of an individual who has in-depth understanding of the external business environment and internal organisation will be vital for SMEs going global. Daily et al. argue that managers with international experience or host country knowledge are favourable when changes happen. SMEs with experienced entrepreneurs and diverse background managerial team members are more likely to achieve efficient and proper decision-making during multinationalisation.

Proposition 6 Individual business experience and managerial team diversity have a positive impact on firm performance in the context of internationalisation.

\section{Strategic legitimacy}

Strategic legitimacy offers a credibility perspective on the firm's ability to deal with changes. In other words, we look at organisations' attributes on 
multinationalisation legitimacy. Firms' strategy-making, risk-tolerance level, market entry model and willingness to bring change to the organisation are all factors which measure this credibility. Firm strategy emphasises whether or not the changes have been considered in firm development. SME internationalisation is a strategic decision and business expansion that needs overall consideration. However, in some cases, for example at the initial stage of exporting, the company may have limited strategic orientation on the cross-national boundary activities. The exporting will stay on as a sales or marketing activity without shifting the whole organisational structure ( $\mathrm{Lu}$ and Beamish, 2001; Shrader et al., 2000). Companies with prior expectation of going global are more likely to put globalisation and consequent impact on organisation into firm strategy. Prior planning and strategy-making enable firms to adapt themselves more quickly to new business models and new marketplace.

Proposition 7 (a) Firms with strategic consideration of internationalisation could more quickly adapt themself to new market and outperform competitors.

The second factor is risk tolerance perspective during market expansion process. Risk tolerance level measures organisation's capability of dealing with risks that come along with internationalisation. There are two kinds of risks in the context of multinationalisation: first, the host country risk, which includes information asymmetry, market unfamiliarity, culture distance and many other concerns conclude as 'freshness cost'; second, the organisational risk, which includes discontinuity of financial support, distance of management, increasing complexity of organisation and other concerns sourced from within the organisation (Shrader et al., 2000). Rasheed (2005) combines two factors, risk tolerance and market entry model, together and proposes that different host market risk level calls for corresponding entry strategy. When the host market risk level is high, non-equity entry may bring down the cost. Frishammar and Andersson (2009) echo Rasheed's proposition and argue that risk-taking in host market has a positive relation with firm's commitment level.

Proposition 7 (b) SMEs with low commitment levels in host country bear lower host market and financial risk exposure.

The last but not least factor is strategic change. Strategic change focuses on firm's change adaptive capability on the strategic level. Strategic change focuses on firm's capability of dealing with change on a strategic level. McDougall and Oviatt (1996) argue that internationalisation brings environmental and organisational changes to a company; these changes should be echoed in firm strategy level otherwise the management efficiency will be in doubt. Environmental contingency theory also supports the view that firm strategy must adapt to 
external environment to achieve managerial harmony (Westhead et al., 2004). More importantly, strategic change is easier and more effective during the early stage of company development (Teece et al., 1997). Although McDougall and Oviatt (1996) empirically tested the relationship between younger and older firms' strategic change difference, a theoretical framework was only established when Autio et al. (2010) argued that young firms have less well-developed substantive and change capabilities which enable the firm to develop a better change capability when entering foreign markets.

Proposition 7 (c) Firms involved in early strategic change achieve higher management efficiency which in turn leads to better host market performance.

\section{Conclusions and future research directions}

Although increasing numbers of studies explore the SME internationalisation, process and consequences, a review of the current status of research is absent. This chapter summarises the prominent theoretical frameworks and empirical evidences of SME internationalisation's impact on firm performance. It defines the frontier of current research by identifying the most prevalent mechanisms and factors that draw on different research perspectives. The significant difference of internationalisation process of SMEs and MNEs has been emphasised. Organisational capability theories, change capabilities and substantive capabilities are the most intensively employed theoretical framework in SME internationalisation analysis. This study includes seven salient mechanisms and 18 factors that are intensively employed in past literatures of SME internationalisation studies: substantive capabilities, for example firm R\&D intensity, knowledge stock and business diversity; change capabilities, for example firm dynamic capability, learning capability and absorptive capacity; strategic management and entrepreneurial demographic characteristics; business manager's personal experience and/or managerial team diversity's impact on SME internationalisation process; market entry model's role in SME internationalisation process; resource-based perspective; and resource position's impact on SME internationalisation process. In a nutshell, this chapter develops a framework of how changes produced by internationalisation activities transfer by different mechanisms to firm performance. Aside from the major findings we mentioned above, the literature review also draws a roadmap of future research areas for the exploration of the mechanisms that influence the SME internationalisation process and subsequent firm performance.

In terms of empirical testing, we propose the following three directions that need to be addressed base on this study. First, resource-dependent perspective has been articulated theoretically in SME internationalisation literatures. The empirical test results of its facilitating effects on SME market expansion 
consequences of such strategic activities. First, it is essential to reduce potential institutional costs for cross-border business activities. This could relieve the initial stage resource drain faced by SMEs when entering foreign markets. Second, encouraging high-tech SMEs to enter the global competition at an early stage could help foster the world's leading technology firms and improve industrial competitiveness in the domestic market. Third, both individual level and regional level networks improve business performance during the internationalisation process. Government should encourage the formation of local industrial clusters and business owner networks. Last but not least, entrepreneurs' knowledge, background and international experience have profound impact on SME internationalisation process. Tolerance of different cultures, positive attitudes towards foreign investment and easy access to modern information and communication technology could provide the essential ground of successful international SMEs.

\section{References}

Audretsch, D. (1997). 'Technological regimes, industrial demography and the evolution of industrial structures', Industrial and Corporate Change, 6(1), 49-82.

Autio, E. (2005). 'Creative tension: The significance of Ben Oviatt's and Patricia McDougall's article "Toward a theory of international new ventures"', Journal of International Business Studies, 36(1), 9-19.

Autio, E., Bruneel, J. and Clarysse, B. (2010). 'Constraint or catalyst? Organisational capabilities and entrepreneurial internationalisation', Imperial College working paper No. 201022.

Autio, E., Sapienza, H.J. and Almeida, J.G. (2000). 'Effects of age at entry, knowledge intensity, and imitability on international growth', Academic Management Journal, 43(5), 909-924.

Avlonities, G.J. and Salavou, H.E. (2007). 'Entrepreneurial orientation of SMEs, product innovativeness, and performance', Journal of Business Research, 60(1), 566-575.

Barney, J. (1991). 'Integrating organizational behavior and strategy formulation research: A resource based analysis', Advances in Strategic Management, 8(1), 39-61.

Bausch, A. and Krist, M. (2007). 'The effect of context-related moderators on the internationalisation-performance relationship: Evidence from meta-analysis', Management Science, 47(3), 319-347.

Bingham, C. (2009). 'Oscillating improvisation: How entrepreneurial firms create success in foreign market entries over time', Strategic Entrepreneurship Journal, 3(4), 321-345.

Coff, R.W. (1999). 'When competitive advantage doesn't lead to performance: The resource-based view and stakeholder bargaining power', Organization Science, 10(2), 119-213.

Cohen, W.M. and Levinthal, D.A. (1990). 'Absorptive capacity: A new perspective on learning and innovation', Administrative Science Quarterly, 35(1), 128-152.

Contractor, F.J. (2007). 'Is international business good for companies? The evolutionary or multi-stage theory of internationalisation vs. the transaction cost perspective', Management International Review, 47(3), 453-475.

Dana, L.P. (2001). 'Introduction: Networks, internationalisation, and policy', Small Business Economics, 16(2), 57-62. 
Dimitratos, P., Lioukas, S. and Carter, S. (2004). 'The relationship between entrepreneurship and international performance: The importance of domestic environment', International Business Review, 13(1), 19-41.

Dimitratos, P., Voudouris, I., Plakoyiannaki, E. and Nakos, G. (2012). 'International entrepreneurial culture: Toward a comprehensive opportunity-based operationalization of international entrepreneurship', International Business Review, 21(4), 708-721.

Dosi, G. (1982). 'Technological paradigms and technological trajectories', Research Policy, 11(3), 147-162.

Dunning, J. (1988). 'The eclectic paradigm of international production: A restatement and some possible extensions', Journal of International Business Studies, 19(1), 1-31.

Fernhaber, S.A., McDougall, P.P. and Oviatt, B.M. (2007). 'Exploring the role of industry structure in new venture internationalisation', Entrepreneurship Theory and Practice, 31(4), 517-542.

Frenz, M. and Gillies, G. (2009). 'The impact on innovation performance of different sources of knowledge: Evidence from the UK Community Innovation Survey', Research Policy, 38(1), 1125-1135.

Frishammar, J. and Andersson, S. (2009). 'The overestimated role of strategic orientations for international performance in smaller firms', Journal of International Entrepreneurship, 7(1), 57-77.

Gaur, A.S. and Kumar, V. (2009). 'International diversification, business group affiliation and firm performance: Empirical evidence from India', British Journal of Management, 20(2), 172-186.

George, G. (2005). 'Slack resources and the performance of privately held firms', Academy of Management Journal, 48(4), 661-675.

Geringer, J.M., Beamish, P.W. and Dacosta, R.C. (1989). 'Diversification strategy and internationalisation: Implications for MNE performance', Strategic Management Journal, 10(2), 109-119.

Gilbert, B.A., McDougall, P. and Audretsch, D.B. (2008). 'Knowledge spillovers and new venture performance: An empirical examination', Journal of Business Venturing, 23(4), $405-422$.

Gray, C. (2006). 'Absorptive capacity, knowledge management and innovation in entrepreneurial small firms', International Journal of Entrepreneurial Behaviour and Research, $12(6), 345-360$.

Hsu, C. and Pereira, A. (2008). 'Internationalisation and performance: The moderating effects of organisational learning', The International Journal of Management Science, $36(2), 188-205$.

Jantunen, A., Puumalainen, K., Saarenketo, S. and Kylaheiko, K. (2005). 'Entrepreneurial orientation, dynamic capabilities and international performance', Journal of International Entrepreneurship, 3(3), 223-243.

Johanson, J. and Vahlne, J.E. (1977). 'The internationalisation process of the firm: A model of knowledge development and increasing foreign market commitments', Journal of International Business Studies, 8(1), 23-32.

- (1990). 'The mechanism of internationalisation', International Marketing Review, 7(4), 11-25.

Keupp, M.M. and Gassmann, O. (2009). 'The competitive advantage of early and rapidly internationalising SMEs in the biotechnology industry: A knowledge based view', Journal of Management, 42(3), 350-366.

Kogut, B. and Zander, U. (1992). 'Knowledge of the firm, combinative capabilities, and the replication of technology', Organization Science, 3(3), 383-397. 
Laufs, K. and Schwens, C. (2014). 'Foreign market entry mode choice of small and medium-sized enterprises: A systematic review and future research agenda', International Business Review, 23(6), 1109-1126.

Li, L. (2007). 'Multinationality and performance: A synthetic review and research agenda', International Journal of Management Reviews, 9(2), 117-139.

Lu, J.W. and Beamish, P.W. (2001). 'The internationalisation and performance of SMEs', Strategic Management Journal, 22(6/7), 565-586.

Malerba, F. and Orsenigo, L. (1993). 'Technological regimes and firm behavior', Industrial and Corporate Change, 2(1), 45-71.

McDougall, P.P. and Oviatt, B.M. (1996). 'New venture internationalisation, strategic change, and performance: A follow-up study'. Journal of Business Venturing, 11(1), $23-40$.

- (2000). 'International entrepreneurship: The intersection of two research paths', Academy of Management Journal, 43(1), 902-906.

McDougall, P.P., Shane, S. and Oviatt, B.M. (1994). 'Explaining the formation of international new ventures: The limits of theories from international-business research', Journal of Business Venturing 9(6), 469-487.

Muscio, A. (2007). 'The impact of absorptive capacity on SMEs' collaboration', Economics of Innovation and New Technology, 16(8), 653-668.

Orser, B.J., Hogarth-Scott, S. and Riding, A.L. (2000). Performance, firm size, and management problem solving', Journal of Small Business Management, 38(4), 42-59.

Oviatt, B.M. and McDougall, P.P. (1994). 'Toward a theory of international new ventures', Journal of International Business Studies, 25(1), 45-64.

(2005). 'Defining international entrepreneurship and modeling the speed of internationalisation', Entrepreneurship Theory and Practice, 29(5), 537-553.

Pangarkar, N. (2008). 'Internationalisation and performance of small- and mediumsized enterprises', Journal of World Business, 43(4), 475-485.

Penrose, E.T. (1959). The Theory of the Growth of the Firm. New York: John Wiley.

Qian, G. (2002). 'Multinationality, product-diversification, and profitability of emerging US small and medium-sized enterprises', Journal of Business Venturing, 17(1), 611-633.

Rasheed, H.S. (2005). 'Foreign entry mode and performance: The moderating effects of environment', Journal of Small Business Management, 43(1), 41-54.

Rugman, A.M. and Verbeke, A. (1992). 'A note on the transnational solution and the transaction cost theory of multinational strategic management', Journal of International Business Studies, 23(4), 761-771.

Rumelt, R.P. (1984). Towards a Strategic Theory of the Firm: Competitive Strategy. Englewood Cliffs, NJ: Prentice Hall.

Sapienza, H.J., Autio, E., George, G. and Zahra, S.A. (2006). 'A capabilities perspective on the effects of early internationalisation on new venture survival and growth', Academy of Management Review, 31(4), 914-930.

Shane, S. and Venkataraman, S. (2000). 'The promise of entrepreneurship as a field of research', Academy of Management Review, 25(1), 217-226.

Shimizutani, S. and Todo, Y. (2008). 'What determines overseas R\&D activities? The case of Japanese multinational firms', Research Policy, 37(1), 530-544.

Shrader, R.C., Oviatt, B.M. and McDougall, P.P. (2000). 'How new ventures exploit tradeoffs among international risk factors: Lessons for the accelerated internationalisation of the 21st century', Academy of Management Journal, 43(6), 1227-1247.

Shuman, J. and Seeger, J. (1986). 'The theory and practice of strategic management in smaller rapid growth firms', American Journal of Small Business, 11(1), 7-18. 
Sullivan, D. (1994). 'Measuring the degree of internationalisation of a firm', Journal of International Business Studies, 25(2), 325-342.

Szulanski, G. (1996). 'Exploring internal stickiness: Impediments to the transfer of best practice within the firm', Strategic Management Journal, 17(S2), 27-43.

Teece, D.J. (1986). 'Profiting from technological innovation: Implications for integration, collaboration, licensing and public policy', Research Policy, 15(6), 285-305.

(2007). 'Explicating dynamic capabilities: The nature and microfoundations of sustainable enterprise performance', Strategic Management Journal, 28(13), 1319-1350.

Teece, D.J., Pisano, G. and Shuen, A. (1997). 'Dynamic capabilities and strategic management', Strategic Management Journal, 18(7), 509-533.

Vernon, R. (1971). 'Sovereignty at bay: The multinational spread of U.S. enterprises', Thunderbird International Business Review, 13(4), 1-3.

Welch, L.S. and Luostarinen, R. (1988). Internationalisation: Evolution of a Concept: The Internationalisation of the Firm. London: Thomson.

Westhead, P., Wright, M. and Ucbasaran, D. (2004). 'Internationalisation of private firms: Environmental turbulence and organizational strategies and resources', Entrepreneurship and Regional Development, 16(6), 501-522.

Wright, M., Westhead, P. and Ucbasaran, D. (2007). 'Internationalisation of small and medium-sized enterprises (SMEs) and international entrepreneurship: A critique and policy implications', Regional Studies, 41(7), 1013-1030.

Zahra, S.A., Ireland, R.D. and Hitt, M.A. (2000). 'International expansion by new venture firms: International diversity, mode of market entry, technological learning, and performance', Academy of Management Journal, 43(5), 925-950.

Zahra, S.A. and George, G. (2002). 'Absorptive capacity: A review, reconceptualization, and extension', Academy of Management Review, 27(2), 185-203.

Zahra, S.A., Sapienza, H. and Davidsson, P. (2006). 'Entrepreneurship and dynamic capabilities: A review, model and research agenda', Journal of Management Studies, 43(4), 917-955. 